Dariusz Jarosz

Warszawa

\title{
Codzienna mobilizacja O propagandzie czytelnictwa książek w Polsce stalinowskiej i trudnościach jej badania ${ }^{1}$
}

\begin{abstract}
Aby zobrazować istotę problemu, który stanowi główny temat moich refleksji chciałbym posłużyć się dwoma cytatami. Pierwszy pochodzi ze sprawozdania z jednego ze zjazdów czytelniczych (w Bukowinie Tatrzańskiej), które odbywały się w związku z III konkursem czytelników wiejskich. Dowiadujemy się z niego, że jego uczestniczka „mówiąc o książkach przeszła na wspomnienia $\mathrm{z}$ własnego życia, nawiązała do życia w Polsce Ludowej - $\mathrm{Z}$ głębokim wzruszeniem mówiła o tym, że ona, która niegdyś żyła w nędzy jest dziś honorowana jako góralka grająca na skrzypcach, że była na dożynkach w Poznaniu i Krakowie, w zespole artystycznym, bo na kursach ZSCh nauczono ją muzyki, a kiedyś marzyła o tym beznadziejnie. „Gdy patrzę na osiągnięcia Polski Ludowej, chciałabym, żeby wszyscy widzieli to, co ja widzę, ja, co jestem już niemłoda. Chciałabym, żeby młodzież rozumiała ile ma od władzy ludowej”. W pewnej chwili góralka przemawiająca z sali „w zapale i wzruszeniu” zaczęła przepychać się wśród zebranych, żeby dotrzeć do prezydium zlotu i ku głębokiemu wzruszeniu całej sali wolała w uniesieniu, powtarzając kilkakrotnie: ,za to wszystko pracuj i groj górolu na chwałę komunistycznych wodzów, pracuj i groj“. Jej wystąpienie „sala przyjęła z entuzjazmem wiwatując na cześć Bieruta i przyjaźni polsko-radzieckiej”2.
\end{abstract}

${ }^{1}$ Rozszerzona wersja referatu przygotowanego na konferencję naukową „Druk i biblioteka w życiu codziennym”, zorganizowaną przez Oddział Warszawski Polskiego Towarzystwa Bibliologicznego i Instytut Informacji Naukowej i Studiów Bibliologicznych Uniwersytetu Warszawskiego 10 maja 2011.

2 Archiwum Akt Nowych (dalej: AAN), Zarząd Główny Związku Samopomocy Chłopskiej (dalej: ZG ZSCh), 1492, Ocena przebiegu rejonowych zlotów czytelnictwa oraz Zlotu Centralnego [1954]. 
Drugi cytat pochodzi z wystąpienia na naradzie aktywu czytelniczego z 30 października 1955 r. Antoni Korzycki, prominentny działacz ówczesnego zniewolonego ruchu ludowego, oceniając koncepcje nowego konkursu czytelniczego Związku Samopomocy Chłopskiej nalegał, aby tym razem stworzyć ,gromadzki plan czytelniczy, nie tzw. znów pisanie fantazji, bo powiedzmy krytycznie, w poprzednich konkursach dużo było wzajemnego okłamywania, nie wszystko było prawdziwe, wielu ludzi szkliło sobie wzajemnie oczy i my teraz chcemy uniknąć szklenia tych wszystkich spraw i chcemy po nowemu ten sezon nowy jesienno-zimowy wykorzystać dla szerokiego dojścia do każdej chałupy, do każdej rodziny, do każdego mieszkańca wsi”’3.

To, co wydaje się najbardziej charakterystyczne dla tych dwu wypowiedzi to dychotomia w ocenie roli państwa w rozwijaniu kultury, w tym zwłaszcza czytelnictwa w stalinizmie. Pytanie podstawowe jakie niemal instynktownie rodzi ich porównanie dotyczy prawdziwości zawartych w nich ocen.

Próba odpowiedzi na nie otwiera przysłowiową puszkę Pandory. Co ona bowiem oznacza? Wszak nie może chodzić o zerojedynkowe orzeczenie: „prawda-fałsz”, bo takie postawienie problemu ze swej natury nie sprzyja wyjaśnianiu rzeczywistości społecznej, zwykle bardzo skomplikowanej i niejednoznacznej. Jak więc tą niejednoznaczność opisać, zniuansować, wyważyć racje „za” i „przeciw”? Idąc dalej: jakie trudności analityczne sprawiają przekazy źródłowe na temat czytelnictwa w okresie stalinizmu, wreszcie - na ile charakter systemu władzy odcisnął swe piętno na źródłach, które służą nam do odtworzenia elementów rzeczywistości społecznej? Mówiąc inaczej: spróbujmy zastanowić się nad tym, przed jakimi podstawowymi trudnościami stoi badacz czytelnictwa (i nie tylko) w PRL w latach 1948-1956 i jak może sobie z nimi radzić. Oto niektóre $z$ nich.

Problem najważniejszy, choć o charakterze propedeutycznym, warsztatowym to umiejętność odszukania i skompletowania źródeł. Będąc przede wszystkim konsumentem publikacji naukowych z zakresu historii książki, bibliotek, wydawnictw, pisanych przez bibliologów dochodzę do wniosku, że PRL, a zwłaszcza Polska stalinowska dopiero zaczyna być przedmiotem ich badań. Ich „klasyczny” warsztat badawczy, przyzwyczajenie do eksplorowania pewnych typów źródeł może być w przypadku zagadnień, o których piszę, nie tylko (i nie tyle) szansą co ograni-

${ }^{3}$ AAN, ZG ZSCh, 1515, k. nlb., Protokół z Centralnego Zlotu Przodowników Czytelnictwa Wiejskiego odbytego w dniu 15 lipca 1955 r. w Auli Uniwersytetu Poznańskiego. 
czeniem. Bibliolodzy, którzy na ten temat piszą, instynktownie (i w zasadzie słusznie) odwołują się do źródeł, zgromadzonych w archiwach centralnych i regionalnych, ale głównie (a czasami wyłącznie) w zespołach instytucji kultury. Tymczasem głębsza znajomość zasobów tych archiwów wskazuje, że taka kwerenda winna być znacznie szersza i co jakiś czas weryfikowana w związku z nowymi dopływami źródłowymi. Który bowiem z „klasycznych” bibliologów wykorzystywał w swych badaniach nad PRL materiały zawarte $w$ tak z pozoru nudnych i mało związanych z kulturą zespołach archiwalnych jak Związek Samopomocy Chłopskiej, Ministerstwo Rolnictwa, Powszechna Organizacja „Służba Polsce” czy Ministerstwo Kontroli Państwowej? Chciałbym, aby to pytanie jak najszybciej przestało być retorycznym.

Problem kolejny, niezwykle ważny, to charakter i stan przekazów, jakimi dysponujemy dla udzielenia odpowiedzi na wcześniej postawione pytania. Elementarną zasadą metodologiczną w badaniach historii w ogóle, w tym historii zjawisk społecznych i kultury jest zgromadzenie jak najbardziej wszechstronnej i różnorodnej bazy źródłowej i dokonanie jej krytyki. Polski stalinizm, również w zakresie badań nad książką i czytelnictwem, jest pod tym względem okresem trudnym. Wynika to z kilku przyczyn. Po pierwsze, w zasadzie nie dysponujemy badaniami socjologicznymi z tego okresu, w tym również tymi na temat czytelnictwa. Socjologia jako nauka akademicka została zlikwidowana na początku lat 50., odrodzenie badań społecznych dokonało się w Polsce gomułkowskiej (w 1958 r. powstaje Ośrodek Badania Opinii Publicznej). Po drugie, zaostrzenie cenzury sprawia, że tradycyjnie wykorzystywane w badaniach historycznych takie źródła jak oficjalne publikacje (szczególnie prasa) nadają się bardziej do odtwarzania celów propagandowych władzy niż orzekania o realiach życia społecznego. Po trzecie, spuścizny po wybitnych bibliologach, działaczach kultury z tego okresu sa nieliczne $\mathrm{i}$ - wedle mojej ułomnej wiedzy - jak na razie trudno je traktować jako istotne dla odtworzenia dziejów czytelnictwa w Polsce stalinowskiej.

W tej sytuacji źródłem najważniejszym, często niemożliwym do zastąpienia (i - co gorzej - weryfikacji) są materiały urzędowe, najczęściej o charakterze sprawozdawczym, wytwarzane zgodnie z praktykami charakterystycznymi dla instytucji stalinowskich. Oznacza to ich głęboką polityzację i ideologizację. W czym się to przejawiało w przypadku czytelnictwa i jego propagandy w okresie stalinizmu?

Aby spróbować udzielić odpowiedzi na to pytanie spróbujmy odwołać się do urzędowych przekazów na temat kolejnych etapów konkursów 
czytelniczych, organizowanych w latach 1950-1956. Szczególnie istotne znaczenie w dalszych rozważaniach będzie miał konkurs dla czytelników wiejskich organizowany początkowo przez Zarząd Główny Związku Samopomocy Chłopskiej (ZG ZSCh), a potem przez większa liczbę organizacji w latach 1951-1956 (dla ułatwienia nazywam go konkursem ZSCh). Wynika to zarówno z rangi, jaka mu wówczas przypisywano, jak te $\dot{z}-\mathrm{z}$ relatywnie dobrego stanu zachowania archiwaliów na jego temat. Charakter pomocniczy będą miały dokumenty poświęcone innym imprezom propagującym czytelnictwo w okresie stalinizmu.

To co uderza w sprawozdaniach na ten temat, jakie docierały „do Warszawy” to ich zdominowane przez „magię wielkich liczb”, mających udowadniać skalę wysiłku podjętego dla upowszechnienia książek i prasy. Zgodnie $\mathrm{z}$ tą zasadą liczba czytelników - uczestników konkursu ZSCh corocznie wzrastała; podczas gdy w r. 1950/1 wynosiła 24114 , to w 1952/3 - 175 305, a w 1953/4 - $612680^{4}$.

Podobnie było z konkursem dla uczniów szkół podstawowych i średnich, organizowanym przez Ministerstwo Oświaty przy udziale Związku Młodzieży Polskiej. Z zachowanych danych wynika, że jeżeli w jego drugiej edycji (r. szk. 1952/53) brało udział blisko 0,5 mln uczniów, to w piątej (1955/1956) - prawie $2 \mathrm{mln}^{5}$. Nie koniec na tym. Osobne konkursy organizowały związki zawodowe wspólnie z ZMP. Ponadto, propaganda książki i rozwój czytelnictwa to było jedno z najważniejszych zadań organizowanych corocznie Dni Oświaty Książki i Prasy ${ }^{7}$ Wielka kampania propagandowa towarzyszyła również walce $\mathrm{z}$ analfabetyzmem; liczba absolwentów nauczania początkowego (według stanu w dniu 1 grudnia 1951 r.) miała wynieść na wsi 486 361, a w mieście $131937^{8}$.

Odnosi się wrażenie, że nie było możliwe, aby obywatel PRL w okresie stalinizmu, pełniąc różne role społeczne, nie zetknął się ze słowem pisanym, do czytania którego intensywnie go namawiano.

${ }^{4}$ AAN, ZG ZSCh, 1484, k. nlb., Uczestnicy konkursu czytelniczego ZSCh, s. 74-75.

5 AAN, Ministerstwo Oświaty (dalej: MOśw.), 7051, k. 36, Konkursy czytelnicze 1951/52-1956/57.

${ }^{6}$ AAN, Zarząd Główny Związku Młodzieży Polskiej (dalej: ZG ZMP), 451/VII-46, k. 53-54, Konkurs czytelniczy Związków Zawodowych i Związku Młodzieży Polskiej [1955].

${ }^{7}$ Szerzej na ten temat pisze w artykule Dni Oświaty Ksią̇ki i Prasy w systemie propagandy kulturalnej wtadz Polski Ludowej 1946-1956, „Polska 1944/45- 1989. Studia i materiały", t. 10, Warszawa 2011, s. 43-60.

${ }^{8}$ T. Pasierbiński, Problemy likwidacji analfabetyzmu w Polsce Ludowej, Warszawa 1960, s. 68 i 121. 
Autorzy analizowanych sprawozdań uznają za oczywiste, że akces do konkursu czytelniczego jest wielką kampanią polityczną. W przypadku konkursu ZSCh oznaczało to, że struktury terenowe związku i innych organizacji realizowały wcześniej ustalone liczbowe limity uczestników konkursu szczególowo rozpisane na województwa, powiaty i wsie ${ }^{9}$. Tak materializował się imperatyw wszechobecnego planowania jako jednej z podstawowych zasad konstytutywnych funkcjonowania stalinowskiego systemu władzy, w tym szczególnie organizacji aktywności społecznej. W sposób charakterystyczny pisano o wykonaniu planu „werbunku” [sic!] do konkursu ${ }^{10}$, co było powodem do dumy.

Wspólne dla tych materiałów, niezależnie od czasu, w którym powstały, jest przekonanie o tym, że czytelnictwo ma być przede wszystkim środkiem do osiągania celów wyznaczonych przez władze państwowe. Książka, tak jak prasa, miała spełniać przede wszystkim funkcję agitacyjną, miała czynić życie czytelników lepszym. I tak ze sprawozdania dotyczącego II konkursu czytelników wiejskich dowiadujemy się, że dzięki niemu „wiele młodzieży porzuciło pijaństwo i karty” ${ }^{11}$. Z województwa rzeszowskiego we wrześniu 1952 r. donoszono, ze „zespoły czytelnicze wpływały na zmianę psychiki chłopa na wsi”, o czym „może świadczyć najlepiej fakt", że na ich bazie powstawały komitety założycielskie spółdzielni produkcyjnych ${ }^{12}$.

Użyteczność książki miała więc polegać również na zmianie mentalności (owej „psychiki”) czytelników, jego wizji historii i polityki. Ten pożądany kierunek ewolucji reprezentuje wypowiedź uczestnika konkursu ZSCh z 1953 r., który uzasadniając swe gusta czytelnicze pisał: „W książce pt. «Żołnierze czterech rzek» najbardziej podobały mi się walki wojska polskiego które powstało z najlepszych synów naszej Ojczyzny którzy u boku Armii Radzieckiej walczyli o zdobycie naszej stolicy Warszawy, Kołobrzegu i Berlina. W książce pt. «KPP w walce o wolność Polski Lu-

${ }^{9}$ Zob. m.in.: AAN, Centralny Urząd Wydawnictw, Przemysłu Graficznego i Księgarstwa (dalej: CUWPGiK), 377, k. 12, Bogdan Zaporowski, Krytyczna ocena stanu czytelnictwa, upowszechniania książki i prasy przez ZMP w organizacji i na odcinku młodzieżowym, Warszawa, 1 XI 1953; AAN, ZG ZSCh, 1486, Wyciąg ze sprawozdania z wyjazdu służbowego kol. Kąkoleckiego z terenu województwa lubelskiego w dniach 21-23 III 1951; AAN, ZG ZSCh, 1488, k. 15, Ocena przebiegu II etapu konkursu czytelniczego na terenie województwa rzeszowskiego [IX 1952].

${ }^{10}$ Zob. m.in.: AAN, ZG ZSCh, 1496, k. nlb., Komunikat Wojewódzkiej Komisji Konkursu Czytelniczego w Poznaniu w sprawie IV Etapu Konkursu Czytelników Wiejskich, Poznań 16 listopada 1953; tamże, Informacja o przebiegu werbunku do IV-go etapu konkursu czytelniczego na terenie woj. rzeszowskiego, Rzeszów 2 XII 1953.

11 AAN, ZG ZSCh, 1489, k. nlb., II etap konkursu czytelniczego [1952].

${ }^{12}$ AAN, ZG ZSCh, 1488, k. 15, Ocena przebiegu... 
dowej» ładny fragment był kiedy najlepsi synowie Polski Ludowej walczyli o obalenie kapitalizmu w Polsce. [...] KPP nigdy nie załamała się w walce z kapitalizmem. Obecnie PZPR opiera się na tradycjach KPP. Tę książkę chciałbym mieć na własność gdyż bardzo dużo mi dała i pogłębiła moją wiedzę"13. Podobnie „wzorowy” z punktu widzenia państwowej ideologii charakter miała wypowiedź ucznia z Leśnej Podlaskiej, pow. Biała Podlaska - uczestnika konkursu czytelniczego Ministerstwa Oświaty, który oceniając książkę $O$ człowieku który się kulom nie ktaniat w 1952 r. pisał o jej bohaterze: „Podobał mi się jego niezłomny charakter. Od młodych lat widzimy Karola Świerczewskiego w fabryce, gdzie pracował na chleb dla rodziny po śmierci ojca. Potem porzuca rodzinne miasto i walczy przeciwko faszystom w Hiszpanii. Wreszcie walczy o wolność Polski u boku Armii Czerwonej. Na progu wolności zginął zabity przez faszystów"14.

Czy jednak propaganda czytelnictwa była tak skuteczna, jak wskazują cytowane przekazy źródłowe? Czy zachowane materiały sprawozdawcze dają szansę na weryfikację tego optymistycznego obrazu? Odpowiedź na to pytanie nie może być zdecydowana i wskazuje na kolejną trudność badacza czytelnictwa korzystającego z wytworzonych w stalinizmie sprawozdawczych materiałów źródłowych.

Ta trudność to wynikająca $\mathrm{z}$ charakteru systemu społeczno-politycznego wyjątkowa „wrażliwość” tych materiałów na wszelkie wahnięcia koniunktury politycznej, i to nie tylko w Polsce. Ważne było nie tylko to, kto pisał, ale również - kiedy. Okres 1948-1956 bynajmniej nie był monolitem. Niektórzy badacze twierdzą, że dla unarodowienia dopuszczalnego kanonu lektur i ich autorów ważne było opublikowanie w 1951 r. pracy Józefa Stalina Marksizm a zagadnienia językoznawstwa 1950 (Biblioteka Klasyków Marksizmu-Leninizmu) ${ }^{15}$. Najważniejszą jednak cezurę we-

${ }^{13}$ AAN, Ministerstwo Kultury i Sztuki, Centralny Zarząd Bibliotek (dalej: MKiS-CZB), 41, k. nlb., Wypowiedź pracownika umysłowego, wykształcenie średnie PZPR, gmina Ogardy.

14 AAN, MOśw., 6869, k. 9 i n., Informacja o przebiegu konkursu czytelniczego „Książka - twój przyjaciel” na dzień 5 III 1952 r.

15 Jak twierdzi Stanisław Kondek wypowiedź Stalina miała istotne znaczenie dla kultury. Zachęcała ona do zrehabilitowania ciągłości kulturowej. Arnold Słucki w „Przeglądzie Kulturalnym” napisał, iż wypowiedź Stalina to „sztandar walki o prawa narodowe”. Nagłe uznanie narodu za wartość uniwersalną i niepodważalną, a języka za podstawę procesu kulturowego także w socjalizmie, skłoniło Ważyka do oświadczenia już w $1951 \mathrm{r}$. („Mickiewicz i wersyfikacja narodowa”), iż „żaden poeta nie ma moralnego prawa urabiać według swojego widzi mi się gustu rymowego dzieci robotników i chłopów polskich, dopóki nie zdąży ich uodpornić lektura Kochanowskiego, Krasickiego, Mickiewicza, Słowackiego". S. Kondek, Stracone złudzenia. Kłopoty dysponentów obiegu książki z rzeczywistościa czytelnicza w latach 1952-1955, [w:] Instytucje - publiczność - sytuacje kultury, t. 6, Warszawa 1997, s. 234. 
wnętrzną stanowi śmierć Stalina w marcu 1953 r. Od tego momentu na jednolicie pozytywnym obrazie władzy pojawiają się wewnętrzne rysy, które z czasem są coraz większe.

Czy ta pogłębiająca się destalinizacja miała wpływ na treść materiałów poddanych kwerendzie? Moim zdaniem - tak, aczkolwiek nie zawsze jest to zdecydowana, konsekwentna zmiana jakościowa. Bez wątpienia jednak jest tak, że to przede wszystkim w archiwaliach wytworzonych w latach 1954-1956 (a czasami i wcześniej) można odnaleźć informacje, które pozwalają na podważenie optymistycznego obrazu propagandowego czytelnictwa.

W przypadku konkursu ZSCh już w 1953 r. można znaleźć wzmianki o tym, że sprawozdawczość na ten temat, przekazywana do warszawskiego centrum związku budziła poważne zastrzeżenia. Kontrole dokonane w województwie kieleckim wykazały, że zespoły czytelnicze już wpisane do odpowiedniej sprawozdawczości w sierpniu 1953 r., nic o swym istnieniu nie wiedziały ${ }^{16}$.

Ten nurt krytyki wzmógł się wyraźnie w następnych 2-3 latach. Świadczy o tym chociażby sprawozdanie podsumowujące IV etap konkursu ZSCh w latach 1953/54, sporządzone przez Centralny Zarząd Bibliotek. Przede wszystkim jego autorzy nawet na podstawie oficjalnych sprawozdań docierających z terenu kraju stwierdzili, że wskaźnik uczestników-chłopów gospodarujących indywidualnie wynosił co najwyżej $39 \%$ ogółu uczestników, członków spółdzielni produkcyjnych -7,5\%.

Ponadto wątpliwości co do rzeczywistej lektury wybranych książek przez uczestników konkursu wskazywała analiza ankiet przez nich wypełnianych. Zgodnie z założeniami konkursu czytelnicy, oprócz danych personalnych, mieli w nich umieszczać nazwiska autorów i tytuły wybranych i przeczytanych książek wraz z uzasadnieniem własnego wyboru. Okazało się, że wybory lekturowe nie wykazywały różnic między zainteresowaniami „czytelników do lat 20 i starszych”. Konkludowano: „Jest to objawem niepokojącym, mogłoby dowodzić, że «odpisywanie ankiet» było masowym zjawiskiem"17.

Inna zaskakująca dla autorów sprawozdania cecha tego etapu konkursu to przewaga wśród uczestników kobiet nad mężczyznami. Był to jednak efekt szerszego zjawiska, związanego ściśle z biurokratycznym sposobem zarządzania tą (i nie tylko tą) imprezą propagandową. Urzę-

16 AAN, ZG ZSCh, 1495, k. 209, Informacja o przebiegu pracy przygotowawczej do IV etapu konkursu czytelników wiejskich w województwie Kielce [1953].

${ }^{17}$ AAN, MKiS - CZB, 39, k. 1, IV Etap Konkursu Czytelników Wiejskich 1953/54. 
dnicy ZSCh i innych organizacji oraz instytucji działających na wsi, zmuszani do organizowania wielu podobnych przedsięwzięć, starali się robić to w sposób z jednej strony optymalnie skuteczny, z drugiej - nie wymagający nadzwyczajnego nakładu sił. Ta strategia wyjaśnia po części „nadreprezentację” kobiet wśród czytelników. Okazało się bowiem, że „kobiety często tworzyły osobne zespoły, które znajdowały oparcie bądź w istniejących kołach gospodyń wiejskich lub związane były z zespołem konkursu hodowlanego, kursem szycia, robót ręcznych m.in." 18 .

Stosowanie tej praktyki łączenia przedsięwzięć cieszących się większą popularnością z tymi o mniejszym prestiżu, organizowanymi niejako „przy okazji” potwierdzają również inne dokumenty konkursowe. W ten sposób np. kobiety biorące w konkursie hodowlanym i z tego powodu czytające odpowiednie popularne książeczki o charakterze poradnikowym stawały się eo ipso uczestniczkami konkursu czytelniczego ZSCh, a uczestniczki kursów kroju i szycia w Olsztyńskiem w 1955 r. rzekomo chętnie czytały i dyskutowały nad książkami dotyczącymi higieny, macierzyństwa, chorób itp. ${ }^{19} \mathrm{~W}$ tymże samym roku do konkursu czytelniczego przystąpili wszyscy członkowie amatorskich zespołów teatralnych ZSCh w województwie bydgoskim ${ }^{20}$.

Ta metoda okazała się na tyle skuteczna, że w 1955 r. niektóre Zarządy Wojewódzkie ZSCh zalecały jej stosowanie w dokumentach organizacyjnych kolejnego etapu konkursu $\mathrm{ZSCh}^{21}$.

Nie koniec na tym; analiza dokumentacji archiwalnej wskazuje, że wskazany mechanizm sprawdzał się w placówkach oświatowych. Już w 1953 r. w szkołach województwa gdańskiego prace II konkursu czytelniczego były traktowane jako obowiązkowe zadania lekcyjne ${ }^{22}$.

Chyba jednak najskuteczniejszą metodę osiągania wyjątkowo dużych ilościowych wskaźników czytelnictwa na wsi osiągnięto w 1955 r. w powiecie mogilneńskim. Jak? Oddajmy głos źródłom: „Na uwagę zasługuje fakt, że posterunki MO uzgadniają z Powiatową Komisją Konkurso-

18 Tamże; zob. również: AAN, ZSCh, 1497, k. nlb., MKiS Centralny Zarząd Bibliotek do ZG ZSCh, Warszawa, 5 kwietnia 1954, Uwagi i wnioski w sprawie przebiegu IV etapu Konkursu Czytelników Wiejskich, oparte na podstawie sprawozdań przedstawicieli Centralnej komisji Konkursu Czytelniczego, wyjeżdżających do poszczególnych województw w dniach od 9 do 15 marca 1954 r.

${ }^{19}$ AAN, ZG ZSCh 1516, k. nlb., Konkurs czytelniczy [1955/56].

${ }^{20}$ AAN, ZG ZSCh, 1511, k. nlb., Centralna Komisja Konkursu Czytelników Wiejskich, Sprawozdanie z przebiegu Konkursu Czytelników Wiejskich w 1955/56.

${ }^{21}$ Zob. AAN, ZG ZSCh, 1503, k. 90, Informacja z przebiegu organizowania konkursu czytelniczego 10-lecia, Kielce 7 stycznia 1955.

22 AAN, ZG ZSCh, 1492, k. nlb., Protokół z III posiedzenia Komitetu Organizacyjnego II Konkursu Czytelniczego „Książka - naszym przyjacielem”, Warszawa 2 lutego 1953. 
wą i podejmują się werbunku w miejscowościach specjalnie trudnych i też zaniedbanych. Włączyły się one też do organizowania wieczorów autorskich na wsi".

Posterunek MO Mogilno w Kołodziejewie zwerbował jako czytelników wszystkich członków GRN, pracowników Urzędu Pocztowo-Telekomunikacyjnego, Stacji PKP, Spichrza Zbożowego Państwowych Zakładów Zbożowych, członków ZMP i członków LZS. „Notujemy taki obrazek. Do Pow. Biblioteki Publ. w Mogilnie zgłasza się kierowniczka punktu bibliotecznego z m. Wszedzień i żąda stu nowych książek. Ogólne zdziwienie. $Z$ dalszych wyjaśnień wynika, że określonego dnia stawią się w punkcie nowi czytelnicy zwerbowani przez aktywistów kulturalnooświatowych MO. Kierowniczka punktu bibliotecznego przygotowuje się na ich przyjęcie stara się o poszerzenie księgozbioru. Otrzymuje żądane książki”23. Co prawda praktyka „werbowania” czytelników przy użyciu milicjantów została wkrótce centralnie zakazana ${ }^{24}$, ale dobrze pokazuje tendencję do używania metod nazywanych zwykle administracyjnymi w kampanii propagandy czytelnictwa. Mechanizm ów sprawdzał się wtedy, kiedy biurokrację państwową i aparat etatowy organizacji działających w tym okresie udało się zaangażować w tę kampanię, co nie było regułą. W wielu zarządach ZMP - skarżono się w materiałach sprawozdawczych - „nie traktuje się poważnie problemu czytelnictwa uznając, że ZMP jest od roboty politycznej, a nie od czytelnictwa" ${ }^{25}$.

Wydaje się jednak, że mimo zastosowania tych środków to lokalni bibliotekarze i nauczyciele (na wsi bywało, że były to te same osoby) byli głównymi propagatorami czytania.

Skuteczność tego wysiłku propagandowego, znajdującego wyraz w liczbach „zwerbowanych” czytelników była zróżnicowana przestrzennie. I nie chodzi tylko o zróżnicowanie regionalne. W dokumencie podsumowującym sprawozdawczość, dotyczącą IV konkursu ZSCh, pisano o „zawężeniu pracy propagandowej werbunku uczestników i organizowania zespołów do gmin położonych najbliżej miast powiatowych" i do gromad w pobliżu tych gmin ${ }^{26}$. Wydaje się, że ta uwa-

${ }^{23}$ AAN, MKS-CZB, 35, k. nlb., Kilka szczegółów z Konkursu czytelników wiejskich w powiecie mogilneńskim [1955].

${ }^{24}$ AAN, ZG ZSCh, 1512, k. 39, Protokół z posiedzenia wojewódzkiej Komisji Konkursu Czytelników Wiejskich w dniu 21 listopada 1955, Bydgoszcz, 28 XII 1955.

${ }^{25}$ AAN, CUWPGiK, 377, k. 2, Bogdan Zaporowski, Krytyczna ocena stanu czytelnictwa, upowszechniania książki i prasy przez ZMP w organizacji i na odcinku młodzieżowym, Warszawa, 1 XI 1953.

${ }^{26}$ AAN, ZSCh, 1497, k. nlb., Ocena pracy ZSCh w IV etapie konkursu czytelniczego i wynikające z niej wnioski dla dalszej pracy naszej organizacji; AAN, Centralny Urząd 
ga ma charakter bardziej uniwersalny, odnoszący się nie tylko do tego etapu konkursu.

Ten nurt krytyki realiów propagandy czytelnictwa, wyraźnie wzmocniony po 1953 r. dotyczył nie tylko konkursu ZSCh. W 1954 r. w protokole $\mathrm{z}$ konferencji w sprawie masowych form pracy z książką w szkołach podstawowych, która obradowała 18 maja 1955 r. znajdujemy zapis, że uczniowie - uczestnicy konkursu czytelniczego, zobowiązani do prowadzenia dzienniczków lektury - przepisywali opinie z lat poprzednich ${ }^{27}$.

Krytyce poddawano również sprzedaż książek, zwłaszcza na wsi, gdzie w sklepach GS stanowily zwykle dodatek do chodliwych towarów $^{28}$. O tym, ze nie było to zjawisko incydentalne, świadczą ustalenia z kontroli dziewięćdziesięciu GS SCh w dziewięciu województwach, przeprowadzone w 1953 r. W zależności od wysokości zakupu, „dokłada [...] się coś za złotówkę, czy za 5 złotych”, a tak obdarowani z reguły nie protestowali. Podsumowując to doświadczenie przedstawiciel „Domu Książki” w 1955 r. mówił: „Jak długo mechanicznie, bez pracy nad chłopem, nad czytelnikiem, będzie się dokładać książki do jego wiadra, do płótna m.in., tak długo chłopi nie będą czytać książek. Takie jest zdanie ludzi, którzy mieli już doświadczenie, jakie te mechaniczne środki w swoim czasie przyniosły kolosalne szkody" 29 .

Co autor tych słów miał na myśli - nie wiadomo. Wiadomo jednak, że pogoń za wykonaniem planów skłaniała do umieszczania ich w miejscach zgoła do tego nie przeznaczonych, jak biura sprzedaży węgla, cementu czy nawozów. Książki w ten sposób nabyte budziły jednak gniew i nie były należycie wykorzystane. „Zdarzyło się - relacjonowała w 1955 r. pracownica Powiatowej i Miejskiej Biblioteki w Bochni - że chłop rzucał książkę zapłaconą w biurze w błoto. Trudno pogodzić wykonanie planu sprzedaży z szacunkiem dla książki” 30 .

To ostatnie zdanie mogłoby stanowić efektowną puentę podjętych rozważań. Myślę jednak, że ważniejszy od tej atrakcyjności jest inny, bynajmniej niełatwy do rozstrzygnięcia problem. Będąc mądrzejszymi

Wydawnictw, Przemysłu Graficznego i Księgarstwa 377, k. 52, Wyciąg z syntetycznego opracowania monografii gmin [bd].

27 AAN, M, 6869, k. 396, Protokół z konferencji w sprawie masowych form pracy z książką wśród szkół podstawowych w dniu 18 maja 1955.

${ }_{28}$ AAN, ZG ZSCh, 1503, k. 16-19, Informacja o organizacji i przebiegu Powiatowych Narad Czytelniczych na terenie woj. białostockiego [1955].

${ }^{29}$ AAN, CUWPGiK, 377, k. nlb., Stenogram z pierwszego plenarnego posiedzenia Rady Czytelnictwa i Książki, odbytego w Warszawie, w dniu 15 czerwca 1953 r.

${ }^{30}$ AAN, CUWPGiK, 380, k. nlb., Maria Bielawska, kierowniczka Powiatowej i Miejskiej Biblioteki w Bochni, Śladem książki w Lipnicy Murowanej, Bochnia 27 IX 1955. 
o wiedzę wynikającą z przywileju późniejszego urodzenia niż autorzy cytowanych sprawozdań skłonni jesteśmy podzielać krytyczny punkt widzenia zawarty w sprawozdaniach na temat czytelnictwa, zwłaszcza tych z lat 1954-1956. Instynktownie odrzucamy wizję czytelnictwa wyłaniającą się z propagandowych obrazków chłopów i chłopek wspólnie czytających wybrane ,politycznie poprawne” lektury i przystępujących pod ich wpływem do podejmowania kolektywnych działań (najlepiej - do zakładania spółdzielni produkcyjnych). Czy jednak mówiąc metaforycznie uczestniczka konkursu ZSCh - pisząca pod wpływem przeczytanych lektur: „chciałabym zastosować dojenie owiec ponieważ dotąd jeszcze nie doiłam. Natomiast krzyżowe krycie owiec już zastosowałam" - może dziś wzbudzać tylko uśmiech pobłażania? Czy tego typu deklaracje należy traktować jako wynik ideologicznego zaślepienia, skuteczności indoktrynacji lub - w najlepszym razie - przekłamane świadectwo źródłowe, wymagające weryfikacji? Czy tak je oceniając nie zmieniamy jedynie wektorów ocen o 180 stopni w porównaniu z okresem, w którym zostały odnotowane? Czy czytelnictwo widziane oczami autorów cytowanych sprawozdań okazało się jedynie kolejną komunistyczną kampanią polityczną o niewielkiej skuteczności? Wreszcie - czy zmuszanie do czytania sposobami niepoprawnymi politycznie - takimi jak wzmiankowane wcześniej - nie stanowiło dostosowanej do epoki „błędów i wypaczeń” metody jego rozwoju? To tylko kilka pytań, ale w moim przekonaniu fundamentalnych, które uświadamiają, przed jakimi trudnościami stają historycy tej problematyki, jeżeli do jej poznania chcą się zbliżyć.

\section{Summary}

\section{Daily Mobilization}

\section{On Book-Readership Propaganda in Stalinist Poland, and the Obstacles Hindering Enquiries on this Subject}

The author attempts to answer the question, what basic hindrances deter researching the issue of readership in Poland during the period 1948-1956, and how these obstacles can be overcome. In his opinion these difficulties encompass: (1) Acquiring the knowledge how to look for and gather primary sources. The successful researcher needs to transcend methodological barriers, which derive from the habits of historians and book-studies specialists, who tend to work on different kinds of documentation. 